There is an air of gentle, collegial generosity which suffuses this volume. It is pleasing to read, though one sometimes wonders whether it proceeds as much from the collaborative relationships between the authors as from the ambience of their texts. We learn that the Zürich reformers were decent, cordial souls, trying to build a church that was faithful to the Gospel but did not dishonour the valued past. This is not the Zürich of the "fanatic sacramentarians." Maybe that is an important lesson.

EUAN CAMERON

Union Theological Seminary in New York City / Columbia University

\title{
Bednarski, Steven.
}

\section{A Poisoned Past: The Life and Times of Margarida de Portu, a Fourteenth- Century Accused Poisoner.}

Toronto: University of Toronto Press, 2014. Pp. xi, $199+9$ ill. ISBN 978-1-44260477-3 (paperback) \$24.95.

In A Poisoned Past: The Life and Times of Margarida de Portu, a FourteenthCentury Accused Poisoner, Steven Bednarski both narrates a chilling tale of medieval crime and punishment, and presents an interesting study in microhistory. The study itself centres on Margarida de Portu who was accused of "murdering her husband by nefarious means" (xvii). The unfortunate husband, Johan Damponcii, was a modest man who appears to have led a "quiet and unremarkable life" (62). The suspected poisoning and subsequent trial provide a surprisingly clear glimpse into the multiple worlds of fourteenth-century Provence.

The tale itself is fascinating. In 1392, Margarida, a young woman from the small town of Beaumont, married and moved to the more cosmopolitan town of Manosque. Within months of her marriage, Margarida had integrated herself into the fabric of the community. However, it seems that all was not perfect. Almost immediately, Margarida was said to develop the "falling sickness" (epilepsy). Among other complications, this allegedly prevented her marriage from being consummated. There were no other obvious signs of discord.

On an otherwise unremarkable morning, Johan ate a breakfast stew made from dried almonds, oil, and garlic that Margarida had prepared. Margarida 
herself ate very little of this concoction as "it was still morning and she was not hungry" (36). Shortly afterwards, Johan "dropped like a stone" in the field and eventually stumbled home to die in bed. Almost immediately, Johan's influential half-brother accused Margarida of murder and witchcraft. The cases both for and against Margarida are laid out in court transcripts containing testimony from a number of witnesses. These texts reveal a complex tapestry of gender, religion, power, and superstition that serve both to fascinate the reader and to illustrate the complexities of dealing with historical documents.

The book comprises five chapters and a brief introduction describing both the case itself and the author's approach. It also includes a map of the town, reproductions of archival documents, and a "working transcription" of the main court record. There is also a dramatis personae detailing the significant players in the tale. As well as helping the reader keep track of the people and places described in the book, the supplementary material illustrates both the framework and the pieces that the historian uses to tell a story.

As Bednarski states in his introduction, this study is both history and historiography: the unhappy tale of Margarida and Johan and the tale of "a modern historian and his texts." To this end, A Poisoned Past reveals "the working method of the historian and highlights weaknesses, flaws, and dangers" (xviii). Drawing on works by authors such as Natalie Zemon Davis and Carlo Ginzburg, Bednarski summarizes both the benefits and dangers of microhistory, something he frequently illustrates with reference to the historical sources in Margarida's tale.

In chapters 2 through 4, Bednarski presents Margarida's story in detail. Chapter 2 summarizes the evidence given by witnesses including Bila Fossata, a local midwife, and Baudient of Volx, a servant. As well as shedding light on the case itself, his presentation of these testimonies shows that questions of gender and class are not necessarily straightforward. Chapter 3 complicates the case still further by showing Johan's financial legacy and the web of family politics. This chapter serves to illustrate the intricacies of dealing with "not just the language and paleography of the court records, but also their internal structure, generative processes, and formulae" (79). Here, Bednarski's own voice reminds the reader of the role a historian plays in constructing history and making interpretive choices. His fourth chapter offers the reader a discussion of Margarida's character, as well the conclusions of the trial. It introduces and contextualizes the use of torture in trials and the concept of defamation. 
The fifth, and final, chapter both presents the aftermath of Margarida's trial and reflects on the study as a whole. In particular, Bednarski analyzes the microhistory he has just presented. In particular, he tells the reader of his reasons for a particular interpretation or line of enquiry, which complements the pedagogical strengths of this study.

The case of Margarida de Portu is a fascinating one, and Bednarski's detailed archival work has yielded a rich source base. At the same time, his nuanced presentation and engaging language, together with self-reflective analysis, would work well for classroom use: particularly for advanced undergraduate students or those beginning postgraduate study. The ideal secondary source for a classroom is one that shows students what the world of scholarship looks like. Bednarski's careful analysis and remarkable self-reflexivity reveal the potential problems of a microhistory, while showing students how to assess, evaluate, and piece together problematic historical evidence. Moreover, Bednarski reminds the reader that there are further discoveries to be made and alternate ways to read evidence. From this, one can hope that Bednarski's study will encourage students to gain the skills he presents here.

ALISON MORE

University of St. Michael's College in the University of Toronto

Bertolet, Anna Riehl, and Carole Levin, eds.

Creating the Premodern in the Postmodern Classroom: Creativity in Early English Literature and History Courses.

Medieval and Renaissance Texts and Studies 537 / MRTS Texts for Teaching 11. Tempe: Arizona Center for Medieval and Renaissance Studies, 2018. Pp. xx, $227+21$ ill. ISBN 978-0-86698-594-9 (paperback) US\$40.

One contributor to this volume, Karolyn Kinane, begins her essay by confessing her former "private fear" that creative projects are somehow "anti-intellectual" and inappropriate for undergraduates (193). I suspect that many other instructors share her fears, and it is a great strength of Anna Bertolet and Carole Levin's collection that it goes a long way to dispelling them. Serving as a "toolbox for teachers," Creating the Premodern in the Postmodern Classroom argues for increasing the use of creative assignments in the university classroom 